\title{
Has the Euro Boosted Equity Markets in the Euro Area?
}

\author{
Maher Asal, Ph.D. (Corresponding author) \\ Associate Professor in Finance at University West \\ 46186 Trollhättan, Sweden \\ Tel: 46-520-22-3664Ｅ-mail: maher.asal@hv.se
}

Received: August 5, 2012

Accepted: August 23, 2012

Online Published: August 28, 2012

doi:10.5430/jbar.v1n2p51

URL: http://dx.doi.org/10.5430/jbar.v1n2p51

The author would like to thank the participants from the 69th International Atlantic Economic Conference organized by the International Atlantic Economic Society (IAES) in Athens, Greece, from March 16-19, 2011.

\begin{abstract}
This paper analyses the impact of the Euro on the development of equity markets in the Euro area and compares the results with those of the United States, UK, and Japan. Specifically, using data on 11 EMU countries from 1990-2010, we examine the impact of the Euro on different measures of stock market size, market liquidity, and concentration. It then uses a variety of ARFIMA and GARCH models to test whether the volatility returns have decreased following the introduction of the Euro. We found that the Euro enhances the depth and the liquidity in Euro area equity markets and that concentration and the unconditional volatility of returns have significantly increased in most Euro area equity markets. Furthermore, although our results identify the United States, Italy, Greece, and Euronext as the fastest growing markets on aggregate, it identifies Ireland and Germany as the lowest growing markets when information on market size, liquidity measures, volatility, and concentration measures
\end{abstract}

Keywords: Liquidity, Concentration, ARFIMA and GARCH

JEL G11.C22.C01

\section{Introduction}

There is overwhelming evidence that integration of the Euro area equity markets has significantly increased since the introduction of the Euro in 1999, and it is considered as a source of potential benefits. First, there is considerable evidence that the EMU resulted in a reduction in the equity cost of capital (Hardouvelis et al., 2007). A lower cost of equity capital, in turn, increases liquidity and investment as the net present value and risk premium rise, boosting GDP. Second, the liberalization of capital markets in Europe has had an effect, and portfolio compositions are becoming more similar. Reduction in barriers to capital mobility with exchange rates no longer barriers to equity trading in the Euro area, a number of empirical research studies have found increased correlation among the performance of national stock markets and an overall increase in the degree of co-movement between European equity markets upon the introduction of the single currency (Asal, 2011; Cappiello et al., 2010 and Adjaouté and Danthine, 2004). As a result, portfolios have begun to be allocated along pan-European sectoral lines rather than on a country basis. Furthermore, a number of innovations to reduce the fragmentation of securities settlement systems, such as the Eurosystem's TARGET2- Securities (T2S) project and the industry Code of Conduct for Clearing and Settlement, are intended to improve further liberalization of securities markets in Euro Area.

Third, several empirical studies presented evidence that the introduction of the Euro and on-going financial market integration has increased risk sharing and income smoothing through the cross-border ownership of assets portfolio diversification (e.g. Kalemli-Ozcan et al., 2003). Fourth, integration may make a country vulnerable to economic and political turmoil abroad making the domestic market more volatile. Volatility, in turn, has adverse implications for liquidity and, hence investment. None of the studies, however, attempts to distinguish the behavior of the stock market development cycles before and after the launch of the Euro.

Although the elimination of currency exchange risk and the high degree of integration probably have substantial positive effects on diversification, risk sharing, cost of capital, and the competitiveness of the EMU economies, their implications for equity market developments are somewhat ambiguous. At a more essential level, economists have 
neither a common model nor a common measure of stock market development. Subsequently, we know very little about the impact of the Euro on equity market development in the Euro area.

This paper examines the impact of the Euro on equity market development in Euro countries and compares the results with those of the United States, the UK, and Japan. It starts by evaluating the impact of the Euro and the resulting financial integration on a set of different indicators of equity market developments; size, liquidity, and concentrations. It then uses a variety of ARFIMA and GARCH models to test whether the volatility returns have decreased following the introduction of the Euro. Since each indicator suffers from statistical and theoretical shortcomings, using diversity of indicators would offer a more accurate picture of stock market development across countries. Furthermore, it is well known that stock market development is a complex concept and no single measure will capture all aspects of this development. The empirical analysis is conducted using data from eleven Euro countries, the United States, the UK, and Japan over the period 1990 -2010.

The rest of this paper is organized as follows. Section 2 discusses the hypothesis about the impact of the Euro on equity market development and reviews the empirical findings found in the literature. Section 3 presents and examines the impact of the Euro on different indicators of stock market development using data from 11 EMU equity markets compared to those markets of the United States, the UK, and Japan. The main empirical methodology and the results along with an array of specification tests are also provided in this section. Section 4 summarizes the main findings and concludes.

\section{Equity Market Developments and the Euro}

There are several channels through which the creation of the EMU could affect developments of the Euro area equity markets. First, the Euro leads to a decrease in transaction costs, such as the cost of currency conversion and currency risk, which increase intra-European capital inflow. Lower transaction costs increase the demand for every stock traded in the Euro zone, which in turn, decreases liquidity risk and surge trading activities. As for the supply of stocks, firms in Euro will have access to a larger pool of funds, and they will no longer be limited by the supply of local funding. Thus, the size and the liquidity of European equity markets and the diversification opportunities available to European investors are expected to increase following the introduction of the Euro. Furthermore, increased competition between stock exchanges boosted by the elimination of exchange rate risks enables the shift from traditional bank-based funding towards a more equity market-based funding. As equity markets grow in size, utilization of economies of scale becomes better with the emergence of stock exchanges. The consolidation of stock markets, the merger of exchanges in Amsterdam, Brussels, Paris, and Lisbon in Euronext and the integrated Nordic-Baltic market, which includes the stock exchanges of Copenhagen, Stockholm, Helsinki, Tallinn, Riga, and Vilnius are good examples.

Second, the common currency abolishes the various boundaries within the EU on the foreign currency compositions of assets held by local institutional investors like life insurance companies and pension funds. These institutions were constrained from holding an optimal portfolio of worldwide assets by maximum weights on assets denominated in foreign currency. Moreover, adapting a common currency improves transparency and standardizes valuation of equities in EMU, thus reducing adverse selection and moral hazard, while alleviating liquidity problems in financial markets (Stulz, 1999 and Mishkin, 2001). Third, another channel through which the removal of barriers can spur domestic stock market development is increased competition. As the Euro area equity markets become more integrated, firms in the less financially developed countries can access major financial centers more easily by listing on foreign stock exchanges. They may want to do so for different reasons: overcoming equity rationing in the domestic market, reducing their cost of capital by turning to a more liquid market, signaling their quality by accepting the scrutiny of more informed investors, or the rules of a better corporate governance system (Pagano et al., 2001). Fourth, volatility of the European stock markets is another implication of the Euro. The question is having convergence of European economics and the introduction of the Euro generated some effects on the volatility of returns in the Euro area's stock markets? Economic theory suggests that stabilization of fundamentals should decrease the variance of stock returns for historically unstable stock markets (Morana and Beltratti, 2002). Cappiello et al., 2010, found that after 1999 the degree of co-movements among the Euro area national equity markets was augmented. Bartrama and Karolyi, 2006, found that although the Euro's launch was associated with an increase in total stock return volatility, significant reductions in market risk exposures rose for nonfinancial firms both in and outside of Europe.

The discussion above leads to two main hypotheses which will be tested in this paper:

$H_{0,1}$ : Size and liquidity of the stock markets in the Euro Area have improved considerably since the adoption of the Euro in 1999. 
$H_{0,2:}$ Volatility of returns and concentration in the Euro Area stock markets have decreased since the adaption of the common currency in 1999.

\section{Methodological Framework and the Empirical Evidence}

With more than a decade having passed, it is an appropriate time to assess what the implication of the Euro for equity market development might have been. This section examines the impact of the Euro on an array of stock market development indicators in the Euro area compared to those of the United States, the UK, and Japan. Specifically, we examine measures of (a) market size; (b) market liquidity; (c) market concentration; (d) market volatility, and (e) conglomerate index that aggregates the information contained in measures (a)-(d). We use data from the World Federation of Exchanges, MSCI Global Standard Indices and World Economic Outlook of the international Monetary Fund. The data cover the period 1990-2010 for 11 EMU countries, the UK, the US, and Japan. The data is further divided into two subsample periods; 1990-1998 and 1999-2010 e.g. pre and post Euro. The EMU countries include Austria, Belgium, Finland, France, Germany, Greece, Italy, Ireland, Netherlands, Portugal, and Spain (Note 1). It is important to notice that the impact of Stage Three of the EMU is of a mostly indirect nature, we are not assuming, therefore, that the Euro has created a new economic system which had never been observed before. Rather we would interpret an increase on the market size and liquidity, and a decrease in the unconditional variance of stock returns as the result of the Euro, stemmed from elimination of currency risk.

\subsection{Size of the Euro-zone equity markets}

The main benefit of increased market size is the opportunity for greater diversification. In theory, the reduction in the cost of risks of cross-border transactions allows investors to improve the spread of risk of their holdings and to rebalance portfolios towards assets that were previously too costly in terms of risk-return trade- off of standard portfolio theory. The Euro zone was expected to create a huge equity market with the potential to rival that of the US: in 1994, the combined value of equities in the 11 EMU countries was $\$ 1.7$ trillion, compared to $\$ 4.9$ trillion in the US. In 2010, the combined value of equities reported $\$ 6.0$ trillion $(+7.6 \%$ per annum) in the 11 EMU countries, compared to $\$ 17.2$ trillion ( $+7.5 \%$ per annum) in the US. The annual growth rate for the UK and Japan were $7.1 \%$ and $0.45 \%$, respectively. These figures make the Euro equity markets the fastest growing markets between 1994 and 2010.

To assess the impact of the Euro on the size of equity markets in the Euro area, we examine (a) the ranking of the biggest stock exchanges of the world over the two subsample periods, (b) the market capitalization ratio and (c) the market capitalization as a percentage of world capitalization.

We begin with the examination of the ranking of the biggest exchanges of the world in terms of market capitalization over the period 1990-2010 (Note 2). The New York Stock Exchange (NYSE) is considered to be the world's biggest stock exchange, in terms of market capitalization over the entire sample period 1990-2010. For most of the period NASDAQ has the second highest market cap in the world, followed by the Japan and the UK. In 1990, markets run by Frankfurt Stock Exchange had a market capitalization of $\$ 355.3$ billion, making it the $4^{\text {th }}$ largest exchange in the world. As of December 2010, it had a market capitalization of $\$ 1.43$ trillion, making it the $13^{\text {th }}$ largest exchange in the world. At the same time, markets run by Euronext had a market capitalization of $\$ 2.93$ trillion, making it the $5^{\text {th }}$ largest exchange in the world in December 2010. On the other hand, Shanghai, Hong Kong, Toronto, Bombay and National stock of India emerged as major top ten stock exchanges in terms of market capitalization in recent years. However, the findings so far are not directly informative about the impact of the Euro on the size of the Euro area's equity markets over time. We turn to this issue next.

Table 1 shows the development of market capitalization ratio country-by-country in the Euro area compared to those of the United States, the UK, and Japan over the two subsample periods. As shown, the size of the stock market as percentage of GDP varies considerably across countries. In the pre Euro period, Euronext, Finland, the US, the UK, and Japan all had an average market capitalization ratio greater than 1.0, while Austria had an average market capitalization ratio of 0.16. In the post Euro period, Euronext, Finland, Spain, the UK, and the US all had an average market capitalization ratio greater than 0.85 , while Austria and Germany had market capitalization ratio of less than 0.5. Furthermore, the size of the German stock market is somehow unaffected by the introduction of the Euro, as the market capitalization ratio remained below 0.5 in the two subsample periods.

An important indication of the increasing importance of the Euro area equity market is provided by the statistics on the growth rate of market capitalization ratio. Apart from Finland where the data is not complete, Spain, Austria, Italy, and Greece are considered the fastest growing markets in the Euro area. These findings suggest that there is a "catching-up effect", where the introduction of the Euro and the removal of barriers have brought an improvement in 
the supply of finance in smaller markets and an increase in their depth as measured by domestic stock market capitalization relative to GDP. Third, the growth rates of turnover ratio in most Euro countries surpass that in the United States, the UK, and Japan.

Finally, we examine the development of market capitalization as a percentage of world capitalization for the whole eleven Euro equity markets against those of the United States, Japan, and the UK (Note 3). Figure 1 shows how much each country's percent of world market cap changed on average between 1994- 2010. As shown, even though the Euro area and the US markets gained in the years preceded the introduction of the Euro, the share of these two markets as a percentage of the world fell steadily following the introduction of the Euro. For example, while the Euro area's weight in total world stock market capitalization grew from $12 \%$ to $16 \%(+7.5 \%$ per annum $)$ over the period $1994-1999$, the US weight in total world stock market capitalization grew from $34 \%$ to $48 \%(+7.2 \%$ per annum). The weight for Japan recorded a decline of around 10\% per annum for the same period and the UK's weight in total world stock market remained unchanged at $8 \%$. This can be read as an indication that the bulk of positive impact that EMU has fostered on the size of the Euro area markets took place already in the run-up to 1999.

Between 1999 and 2010, while the Euro area's weight in total world stock market capitalization fell from 17\% to 10\% (-3.6 \% per annum), the US weight fell from $49 \%$ to $30 \%$ (-3,7\% per annum). The annual decline in the UK and Japan were $1 \%$ and $4 \%$, respectively. As in 2010, the US still makes up a third of the world market cap; however, it is more than three times as big as the Euro area. China has the third highest market cap in the world, followed by the UK, Hong Kong, Canada, France, and India. While India and China are still considered emerging markets, they both have bigger market caps than Germany. Thus, despite having grown substantially over the period 1994-1998, the Euro area's cap as a percentage of the world has fallen steadily after 1999 and as of 2010 the Euro area's weight of world cap was less than its weight in 1994. One possible explanation of the worsening of the Euro area's cap as a percentage of the world in recent years could be the fears of a sovereign debt crisis developed among investors concerning some Euro zone members. Greece, Ireland and Portugal and also some EU countries outside the area resulted in valuation effects in an environment of declining asset prices associated with a significant withdrawal of Euro area investors from investment.

\subsection{Liquidity of the Euro-zone equity markets}

While economists advance many theoretical definitions of liquidity, analysts generally use the term liquidity to refer to the ability to easily buy and sell securities. A comprehensive measure of liquidity would quantify all the costs associated with trading, including the time costs and uncertainty of finding a counterpart and setting the trade. Since we want to compare liquidity across countries and across time and since data are very limited, we use three measures of realized trading; the value of share trading ratio, the turnover ratio, and the average daily trading.

\section{1) The Value of Share Trading Ratio}

The first measure of equity market liquidity is the value of share trading ratio, which equals the total value of domestic shares traded on the stock market exchange divided by GDP and thus, it provides information about the aggregate ability of liquidity on an economy-wide basis. A large stock market is not necessarily an active market: a large but inactive market will have a large market capitalization but a small value of share trading ratio and vice versa. Together, market capitalization and total value of sharing traded inform us about market size and liquidity on a macroeconomic scale.

In 1994, the combined value of share trading in the 11 EMU countries was $\$ 1.04$ trillion, compared to $\$ 3.9$ trillion in the US, $\$ 0.86$ trillion in Japan and $\$ 1.03$ trillion in the UK. In 2008 , the combined value of share trading was $\$ 13.4$ trillion ( $+18 \%$ per annum) in the 11 EMU countries compared to $\$ 70$ trillion $(+21$ per annum) in the US. The annual growth rates for the UK and Japan were $12 \%$ and $16 \%$, respectively. These figures make the Euro area the second fastest growing market after the US. However, the above figures are not directly informative about the impact of the Euro on liquidity of the Euro area's equity markets over time. We turn to this issue next.

To assess the impact of Euro on liquidity we examine the development of share trading ratio country-by-country in Euro area versus those of the United States, the UK, and Japan before and after the introduction of the Euro. The results shown in table 2 indicate that the value of share trading ratio varies considerably across countries. In the pre Euro period, Euronext, Germany, the UK, the US, and Japan all had an average value of share traded ratio above 0.20, while Greece and Italy had an average value of share traded below 0.12 . In the post Euro period, Euronext, Finland, Spain, the US, and the UK had total value of share traded ratio of 1.0 or more, though Austria and Greece had a ratio below 0.50. A comparison between the two subsample periods indicates that apart from Finland, Greece, Italy and Euronext were the fastest growing markets in terms of liquidity following the introduction of the Euro. 
We also examine the development of the value share trading as a percentage of the world value of share trading for each country within the Euro area compared to those of the United States, the UK, and Japan before and after the introduction of the Euro. Figure 2 shows how much each country's percent of world share trading changed on average between 1994- 2008. As shown in the figures, both the Euro area and the US value of share trading (\% of world) grew substantially in the years preceding the introduction of the Euro. For example, between 1994 and 1998, while the Euro area's weight in total world value of share trading grew from $11 \%$ to $14 \%(+6.7 \%$ per annum), the US weight in total world value of share trading grew from $41 \%$ to $55 \%(+7.8 \%$ per annum). The growth rate for Japan and the UK were $-22 \%$ and $-6.3 \%$ per annum, respectively. In the post Euro period, whereas the Euro area's weight in total world value of share trading grew at a moderate rate of $0.56 \%$ per annum, the US weight grew at a rate of $0.85 \%$ per annum. Both the UK and Japan had the fastest growth rates of $1.2 \%$ and $11 \%$ per annum, respectively. In sum, although the Euro area's percent of world share trading has increased on average by more than $6 \%$ a year between 1994- 1998, it has then declined on average to $0.5 \%$ a year between 1999-2008. This result, thus, suggests that the bulk of positive impact that EMU has fostered on the liquidity of Euro area markets took place already in the run-up of 1999.

2) The Turnover Ratio

The second measure of equity market liquidity is that the turnover ratio equals the total value of domestic shares traded divided by market capitalization. The turnover ratio measures the trading of domestic equities on domestic exchanges relative to the size of the stock market. High turnover ratio is often used as an indicator of low transaction costs for investors buying and selling shares. Conversely, a lower turnover ratio drives up the impact transaction cost. In addition, a large stock market is not necessarily a liquid market: a large but illiquid market will have a large market capitalization ratio but a small turnover ratio and vice versa. While the value traded ratio captures trading relative to the size of the economy, turnover measures trading relative to the size of the stock market.

Table 3 shows turnover ratio country-by-country for the Euro area, the UK, the US, and Japan over the two subsample periods. As shown, the turnover ratio varies considerably across countries. In the pre Euro period, while Germany, the UK, and the US are considered the most liquid markets where all had an average turnover ratio above than 0.70, Austria, Finland, and Greece all had an average turnover ratio less than 0.4. In the post Euro period, Euronext, Germany, Italy, Spain, the UK, and the US are considered the most liquid market where all had an average turnover ratio above than 1. However, there are also a number of Euro area countries where stock markets are not very liquid e.g. the Austrian, Greek, and Irish markets. Referring to the growth rate of turnover ratio, reported in the last row of Table 3, reveals some interesting facts. First, while the turnover ratio has shown uneven growth between the two subsample periods in most markets, it has more than tripled in Italy and more than doubled in the Euronext and Finish stock exchanges. Second, the lowest growth rate of turnover ratio can be found in Austria, Germany, and Ireland.

As discussed in Kunt and Levine, 1995, and Levine and Zervos, 1996, both the value of share trading and the turnover ratio measures have one potential drawback. If stock prices rise today because of anticipated high profit, the value stock transactions and therefore both indicators would rise without a rise in the number of transactions or a fall in transaction costs. One way to determine the influence of the price effect is to look at market capitalization and value of traded ratio together. The price effect influences both indicators, but only the value-traded ratio is directly related to trading. Another way to examine the importance of the price effect is to examine the turnover ratio. The price effect does not influence the turnover ratio because stock prices enter the numerator and the denominator of the turnover ratio. In addition, the turnover ratio complements the value of share trading ratio. While total value traded ratio captures trading compared with the size of the economy, turnover measures trading relative to the size of the stock market. In other words, a liquid but tiny market on a macroeconomic scale will have a high turnover ratio but a small total value traded. For example, there was not much equity trading in Italy relative to the size of its economy between 1990-1999, but Italy's turnover ratio was high.

Figure 3 displays the time pattern of the average yearly turnover ratio in all of the 11 EMU countries, the United States, Japan, and the UK over the two subsample periods. In the pre Euro period, the average turnover ratio in the 11 EMU countries reported $0.64(+4 \%$ per annum) compared to $0.89(+5 \%$ per annum $)$ in the US, $0.64(+32 \%$ per annum) in the UK, and 0.55 (-16 per annum) in Japan. In the post Euro period, the average turnover ratio in the 11 EMU countries reported $1.32(+15 \%$ per annum) compared to $2.10(+18 \%$ per annum) in the US, $1.62(+10 \%$ per annum) in the UK, and $1.27(+18$ per annum) in Japan. Thus, the figures indicate that Euro area equity markets have become more liquid following the introduction of the Euro and that it is considered the third fastest markets following those of the United States and Japan. 


\section{3) Average Daily Trading}

We also include statistics of the average daily trading as an additional measure of liquidity and the results are reported in table 4. In the pre Euro period, while Germany, Euronext, the UK, the US, and Japan are considered the most liquid markets where all had an average daily trading above $\$ 1.5$ billion, Ireland, Greece, and Austria all had an average daily trading of 0.09 or less. However, in the post Euro period, Euronext, Germany, Italy, Spain, the UK, the US, and Japan are considered the most liquid markets where all had an average daily trading above than $4.2 \$$ billion. Ireland, Greece, and Austria all had an average daily trading of 0.34 or less. As for the growth between the two subsample periods Italy, Greece, Finland, and Euronext are considered the fastest growing markets in terms of daily trading ratio. As for the Euro area as a whole, the average daily trading on Euro area stock exchanges increased by $285 \%$ compared to $240 \%$ and $108 \%$ for the UK and Japan, respectively. The growth of the average daily trades in the United States recorded $742 \%$, which is more than double of the Euro area.

\subsection{Concentration in the Euro area versus the United States, the UK, and Japan}

In some countries a few companies dominate the market. To measure the degree of market concentration, we compute the share of market capitalization accounted for by the five largest stock exchanges and call this measure Concentration. Table 5 shows the development of market concentration of the $5 \%$ of the largest companies by market value in the Euro area, the United States, the UK, and Japan over the two subsample periods. Referring to the figures in table 5, we can simply make three points. First, in most stock markets under examination, the five biggest companies account for a significant slice of total market capitalization. For example, Germany, Italy, Spain, the UK, and the United States all have a concentration above $0.60 \%$ over the period 1994-2010. This high market concentration in EMU limits diversification possibilities for a typical Euro land investor, which is essential for the proper investment decisions. Second, concentration has increased in the post Euro era in all markets, apart from Ireland. The most notable increase in concentration is observed in Finland (+49\%), Austria (+23\%), Euronext $(+16 \%)$, and Spain $(+13 \%)$.

This is a very high percentage of market concentration, which is not desired by the modern theories of portfolio management or for those who want to minimize the risk through risk management and selection of the alternatives or diversifies. It is also very difficult for investors to select the negatively correlated securities in the highly concentrated capital market (Markowitz 1952). Third, despite having grown considerably over the two subsample periods, the Euro area's concentration is still lower than those of the United States, the UK, and Japan. Between 1995 and 2010, while the average concentration in the 11 EMU countries grew from $0.55 \%$ to $0.60(+7.15 \%)$, concentration in the United States grew from $0.62 \%$ to $0.63 \%(+2 \%)$. The growth of concentration in the UK and Japan reported $10 \%$.

\subsection{Volatility of stock return in the Euro area's equity markets}

Has the Euro decreased stock return volatility in the Euro area's equity markets? To answer this question, we have considered the evaluation of the volatility of monthly stock returns for EMU member countries over the period January 1990-2010. For the robustness of the results, we use alternative estimation methods to compute volatility over the two subsample periods; 1990-1998 and 1999-2011 e.g. pre and post Euro. Specifically, we estimate (a) the standard deviation and a $12^{\text {th }}$ order autoregression, (b) F test for the equality of the unconditional variances, (c) autoregressive fractionally integrated moving average model (ARFIMA), and (d) GARCH $(1,1)$ model with Student t-distribution errors. For comparison, we also have analyzed the volatility dynamics of stock returns in the United States, Japan, and the UK.

We start with statistical description of returns in the 11 Euro area countries, the US, the UK and Japan, whose results are reported in table 6 . As shown, the mean varies considerably across countries, in the pre Euro period, whereas the mean of returns in Finland, the Netherlands, Spain and the US averaged above 3\% and the mean of return in Austria and Japan averaged less than 0.5 . Similarly, there are great cross-country differences in the standard deviations of returns. Whereas the standard deviations of returns in Finland, the Netherlands, Spain, and Switzerland averaged above $14 \%$, the standard deviations in Austria and Japan averaged less than $7 \%$. As in the post Euro period, the mean of returns has fallen in all countries, except in Austria and Japan, where the standard deviations have increased remarkably in most countries, particularly in Finland and Spain. Overall, the standard deviations have almost doubled in the EMU, the United States, and the UK. For robustness of the results, we have estimated the $12^{\text {th }}$ order autoregression of monthly returns, including dummy variables whose results are shown in the last two columns of table 6 . The results confirm the previous findings in that volatility has increased in all countries in the post-Euro era, apart from Japan. The highest increase in volatility is observed in Finland, Spain, and Belgium, while the lowest increase is observed in Italy, the Netherlands, and Japan. 
We next perform a preliminary $\mathrm{F}$ test for the equality of the unconditional variances of stock returns before and after the introduction of the Euro, whose results are reported in table 7. As indicated, the null hypothesis of equal unconditional variances in the two subsamples can be rejected for all countries e.g. the variances for the post Euro were significantly larger than the variances for the pre Euro period, except for Japan. For Austria, for example, the variances of the two subsamples were 41.2 and 127.5 and the one tailed calculated F-statistic is 0.32 with a p-value of $\mathrm{p}=0.000$, which reject the null hypothesis of equal variances at $1 \%$ significant level (Note 4 ). The most noticeable increase in volatility is in Finland, Belgium, and Spain

The values of both skewness and excess kurtosis reported in table 6 reject the normality assumption of returns for all countries, which undermines the previous findings. Peters (1991) argues that most financial markets are not Gaussian in nature and tend to have sharper peaks and fat tails. Therefore, a number of traditional methods based on Gaussian normality assumption have their own limitations in providing accurate forecasts. He argues that most financial markets have a very long memory property; i.e., what happens today affects the future forever. Such a long memory component of the market cannot be adequately explained by traditional models describing short-term memory, such as AR (p), MA (q), ARMA (p, q), and ARIMA (q, d, q). A set of models has been established to overcome this difficulty, and the most prominent one is the autoregressive fractionally integrated moving average (ARFIMA or ARFIMA (p, d, q)) model (Note 5).

Table 8 reports the results using ARFIMA $(1,0,1)$ model. As shown, the parameter $\widehat{d}=-0.748$ which is significantly different from zero at $1 \%$ level in which the ARFIMA model for returns seems a better model. Although, the test of additional serial correlation in the error term is only just accepted at the $5 \%$ significant level, the diagnostic tests suggest that the ARFIMA model has severe non-normality problems as well as evidence of ARCH errors. Furthermore, the plot of the residuals suggests that the non-normality problem is due to the existence of outliers, which may also account for the ARCH errors. Given that the ARCH affects the present; we will now see if it is advantageous to formulate a more parsimonious GARCH $(1,1)$ model (Note 6).

The positive excess kurtosis, leptokurtic, reported in table 6 indicates that return distribution is best described by super Gaussian, i.e., student's t-distribution, which motivates the use of the GARCH model with Student-t distributed error to test for the equality of the unconditional variances. To test for the presence of a volatility shift, a dummy variable assuming the value of one starting from 1 January 1999 has been included in the conditional variance equation for all EMU countries apart from Greece, where the dummy starts from 2001. Specifically, following Bollerslev (1987), equity returns, $\mathrm{r}_{\mathrm{t}}$ and variance, $\mathrm{h}_{\mathrm{t}}$ are expressed as:

$$
\begin{aligned}
& r_{t}=\gamma_{0}+h^{1 / 2} \mu_{t}, F_{t-1} t(v) \\
& h_{t}=\alpha_{0}+\alpha_{1} \mu^{2}{ }_{t-1}+\beta_{1} h_{t-1}+\lambda D_{t}
\end{aligned}
$$

The results are reported in table 9 . As can be noticed from the table, normality $\mathrm{Chi}^{2}$ test statistics indicate that it is extremely unlikely that returns were generated by a normal distribution at $1 \%$ significant level, which is not surprising considering the many large residuals. As shown in the table in none of the cases does the dummy have the expected negative sign and it is significant for Belgium, Finland, Portugal, and Greece. Most importantly the dummy is significant and positive for the EMU average returns. The evidence therefore, suggests that following the introduction of the Euro, the unconditional volatility of returns has increased significantly in the EMU, especially in small countries.

\subsection{Correlations among the equity market development indicators}

Table 10 provides the correlations among stock market development indicators we have discussed so far for the Euro area versus the United States, the UK, and Japan. Three important facts merge from this table. First, while the two measures of market liquidity; turnover ratio and value traded ration are insignificantly correlated, the estimated coefficient for the US is positively significant with a value of 0.61 . The two measures thus do not move one for one and are complementary information about stock market development. Second, market size is significantly positively correlated with the total value traded ratio in the EMU, the UK, and Japan. Third, countries with highly concentrated markets also have markets that are less developed using the other indicators. Specifically, market concentration is significantly negatively correlated with market size in the EMU and the UK with coefficient values of -0.10 and -0.40 , respectively. Similarly, market concentration is significantly negatively correlated with the value of share trading in EMU and the UK with coefficient value of -0.10 in each market. Furthermore, the correlation coefficient between market concentration and volatility in the Euro area has a value of 0.30 , which is significant at $1 \%$ level and indicates that as the market concentration increases, risk rises in the Euro zone. Overall, the correlations suggest that the different indicators capture different aspects of stock market development. To measure how well stock markets 
function in general we need to incorporate the information contained in a broad selection of these indicators i.e., compute an index of overall stock market development. We turn to this issue next.

\subsection{Which Stock Market is the most developed?}

So far, we have examined the level and growth of stock market development indicator-by-indictor. We now address the question: which stock markets are the most developed overall before and after the introduction of the Euro? To do this, we construct an aggregated index of stock market development that combines information contained in the five individual indicators discussed above. We then use this index to rank countries in terms of overall stock market development before and after the introduction of the Euro.

In constructing such an index we follow a two-step procedure. First, for each country (i) we compute the means-removed market capitalization, turnover ratio, value of share trading ratio, average daily trading, volatility, and concentration. We define the means-removed value of variable $\mathrm{X}$ for country (i) as: $X(i)^{m}=\frac{|X(i)-\bar{X}|}{\bar{X}}$. Where $\mathrm{X}$ (i) refers to the average of the absolute value of $X$ in country (i) and $\bar{X}$ is the average of the absolute value of $\mathrm{X}$ across the 14 countries under examination. Note, for the volatility and concentration we multiply the indicator numbers by $(-1)$ because larger numbers refer to less stock market development. Second, we sum up the means-removed values for the five indicators to obtain an overall index for each country (Note 7).

Table 11 reports the computed aggregated index and ranking of the overall equity market development over the two subsample periods. Specifically, the index aggregates information on market capitalization, turnover ratio, value of share trading, average daily trading, volatility and concentration. While it is difficult to answer the question posted at the start of this section, "which stock markets are the most developed?", the results suggest the following findings. In the pre Euro period, while the index ranks the United States, the UK, Japan and Germany as having very highly developed equity markets, it ranks Greece, Italy, and Austria as having the least developed equity markets when aggregating information on market size, liquidity measures, volatility, and concentration (Note 8). In the post Euro period, however, while the index ranks the United States, the UK, Japan, and Euronext as having very highly developed equity markets, it ranks Finland, Austria, and Ireland as having the least developed equity markets. Finally, while the results identify the United States, Italy, Greece, and Euronext as the fastest growing markets on aggregate, it identifies Ireland, Germany, and Japan as the lowest growing markets on aggregate (Note 9)

\section{Conclusion}

This paper analyses the impact of the Euro on the development of equity markets in the Euro area and compares the results with those markets of the United States, the UK, and Japan. The main findings can be summarized as follows. First, the Euro stock markets have gained remarkable significance over time. While their size and liquidity are still substantially smaller than that of the US stock market, both in absolute terms and as a ratio of gross domestic product, they are considered the fastest growing markets in terms of size and the second fastest in terms of liquidity between 1994 and 2010. Second, the impact of the Euro on the size and liquidity in each country within the Euro area varies considerably. While there is a considerable increase in stock market size in Finland, Austria, and Greece, the size of the German stock market is unaffected by the introduction of the Euro. These findings suggest that there is "catching-up effect", where the introduction of the Euro and the removal of barriers have brought an improvement in the supply of finance in smaller markets and an increase in their depth. Third, despite having grown substantially over the period 1994-1998, the Euro area's cap and liquidity as a percentage of the world fell remarkably after 1999 and as of 2010 the Euro area's weight of world cap were less than its weight in 1994. Fourth, although concentration has increased in the post Euro era in all Euro area stock markets, apart from Ireland, Euro area's concentration is still substantially smaller than that of the US stock market. The most notable increase in concentration is observed in Finland, Austria, Euronext, and Spain. Fifth, the Euro area's market concentration is significantly negatively correlated with market size and liquidity in the Euro area and is significantly positively correlated with volatility of returns. Sixth, the unconditional volatility in the European stock markets has increased in all EMU countries, especially in small economies. Seventh, in the post Euro period, while the index ranks the United States, the UK, Japan, and Euronext as having very highly developed equity markets, it ranks Finland, Austria, and Ireland as having the least developed equity markets when aggregating information on market size, liquidity measures, volatility, and concentration. Furthermore, while the results identify the United States, Italy, Greece, and Euronext as the fastest growing markets on aggregate, it identifies Ireland, Germany, and Japan as the lowest growing markets on aggregates. Overall, though Euronext, Italy, and Greece may have been the biggest gainers, Germany and Ireland are the major losers following the introduction of the Euro. 


\section{References}

Adjaouté, K. \& Danthine, J.P. (2004). Portfolio diversification: alive and well in Euroland. Applied Financial Economics, 14, 1225-1231. http://dx.doi.org/10.1080/0960310042000203028

Andersen, G., \& Bollerslev, T. (1997). Answering the Critics: Yes, ARCH Models Do Provide Good Volatility Forecasts. NBER Working Papers 6023, National Bureau of Economic Research

Asal, M. (2011). The impact of Euro on sectoral equity returns and portfolio risk. International Advances in Economic Research, Vol. 17, 2011.

Baillie, R.T. (1996). Long memory processes and fractional integration in econometrics. Journal of Econometrics, 73: 5-59. http://dx.doi.org/10.1016/0304-4076(95)01732-1

Bartrama, S. M. \& Karolyi, A. G. (2006). The impact of the introduction of the Euro on foreign exchange rate risk exposures. Journal of Empirical Finance, vol.13, 519-549. http://dx.doi.org/10.1016/j.jempfin.2006.01.002

Bollerslev, T. (1986). Generalized autoregressive conditional heteroskedasticity. Journal of Economterica, 31, 307-327. http://dx.doi.org/10.1016/0304-4076(86)90063-1

Bollerslev, T., \& Ghysels, E. (1994). On Periodic Autogressive Conditional Heteroskedasticity, CIRANO Working Papers 94s-03.

Cappiello, L., Kadareja, A. \& Manganelli, S. (2010). The impact of the Euro on equity markets. Journal of Financial and Quantitative Analysis, vol. 45, p 473-502. http://dx.doi.org/10.1017/S0022109010000086

European Central Bank (2008). Financial integration in Europe.

Granger C.W.J. and R. Joyeux, (1980). An introduction to long-memory time series models and fractional differencing- J. Time Series Anal., 15-29. http://dx.doi.org/10.1111/j.1467-9892.1980.tb00297.x

Hardouvelis, G., Malliaropulos, D., \& Priestley, R. (2007). "The impact of EMU on the equity cost of capital. Journal of International Money and Finance, vol. 26, 305-327. http://dx.doi.org/10.1016/j.jimonfin.2006.12.002

Kalemli-Ozcan, S., Sørensen, E., \& Yosha, O. (2003). Risk sharing and industrial specialization: regional and international evidence. American Economic Review, June 2003, Vol.93 (3), 903-918. http://dx.doi.org/10.1257/000282803322157151

Kunt, A. \& Levine, R. (1995). Stock market development and financial intermediaries. The World Bank, Policy Research working paper no 1462.

Levine, R. \& Zervos, S. (1996). Stock markets, banks, and economic growth. The World Bank, Policy Research Working Paper no 1690.

Markowitz, H.M. (1952). Portfolio selection. Journal of Finance, 7(1), 77-91.

Morana, C. \& Beltratti, A. (2002). The effects of the introduction of the Euro on the volatility of European stock markets. Journal of Banking \& Finance 26.

Mishkin, F. (2001). Financial policies and the prevention of financial crises in emerging market economies," Policy Research Working Paper Series 2683, The World Bank.

Pagano, M., Otto. R. \& Röell, A. \& Zechner, J. (2001). What makes stock exchanges succeed? Evidence from cross-listing decisions. European Economic Review, 45(4-6). http://dx.doi.org/10.1016/S0014-2921(01)00132-5

Pagano, M., Otto. R. \& Röell, A. \& Zechner, J. (2002). The geography of equity listing: why do companies list abroad? Journal of Finance, 57(6), 2651-2694. http://dx.doi.org/10.1111/1540-6261.00509

Peters, E.E. (1991). Fractal Market Analysis: Applying Chaos Theory to Investment and Economics. John Wiley \& Sons, New York.

Roselyne, J. \& Granger, C. (2010). Long Memory Processes. Journal of Financial Econometrics, 8 (2): $184-186$. http://dx.doi.org/10.1093/jjfinec/nbq003

Stulz, M. (1999). Globalization of Equity Markets and the Cost of Capital. NBER Working Papers 7021, National Bureau of Economic Research, Inc.

Schwert, G. (1989). Why does stock market volatility change over time? Journal of Finance, 49(5), pp. $1115-53$. http://dx.doi.org/10.1111/j.1540-6261.1989.tb02647.x 
Notes.

Note 1. We use the terms "EMU" and "Eurozone" interchangeably to mean the set of countries which adapted the Euro as their own currency. Luxemburg is excluded because the size of its equity market is too small.

Note 2. The results are not shown to save space

Note 3. Some may blame the International Financial crisis started in the summer of 2007 for the decreasing growth rate of market capitalization in the Euro area where the Euro area market capitalization declined in 2008 by $48 \%$, New York fell by $41 \%$, and NASDAQ by $40.3 \%$. Indeed, this decline has occurred in all equity markets where world market capitalization also fell by $47.6 \%$ in the same year.

Note 4. A two-sample t-test was also performed that does not assume equal variances and the results reject the null hypothesis of equal variances.

Note 5. For a further discussion on this topic, see Roselyne \& Granger, 2010, and Baillie, 1996

Note 6. The basic ARMA (p,q) model is: $\mathrm{r}_{\mathrm{t}}=\gamma_{0}+\alpha_{1} \mathrm{r}_{\mathrm{t}-1}+\ldots+\alpha_{\mathrm{p}} \mathrm{r}_{\mathrm{t}-\mathrm{p}}+\varepsilon_{\mathrm{t}}+\beta_{1} \varepsilon_{\mathrm{t}-1}+\ldots+\beta_{\mathrm{q}} \varepsilon_{\mathrm{t}-\mathrm{q}},+\lambda \mathrm{D}$.. $\mathrm{t}=1, \ldots, \mathrm{T}$. This assumes that either $\varepsilon_{\mathrm{t}} \sim \mathrm{NID}\left(0, \sigma_{\varepsilon}^{2}\right)$, or $\mathrm{E}\left[\varepsilon_{\mathrm{t}}\right]=0$ and $\mathrm{E}\left[\varepsilon_{\mathrm{t}}^{2}\right]=\sigma_{\varepsilon}{ }^{2}$.

Note 7. For a similar expression, see Kunt and Levine, 1995.

Note 8 . The results here are sensitive to the number of indicators included in the index. For example, including only two measures for liquidity instead of three changes the ranking of the index shown in table 11.

Note 9. We plan to investigate both the underlying causes of this rapid development in Euronext in future research.

Note 10 . Since the $\mathrm{p}$-value is less than 0.05 , this provides evidence that rejects the null hypothesis of equal variances

Note 11. The results remained unchanged after including different dummies to reflect the impact of financial crisis (e.g., Dot-com bubble in 2000 and the global financial crisis in 2008), bank-based and equity-based financial development as well as the level of economic development across the 14 countries. 
Table 1. Market capitalization ratio as a share of GDP in the Euro area, the United States, the UK, and Japan, $1990-2010^{\text {a }}$

\begin{tabular}{lllllllllllll}
\hline \hline & Euronext $^{\mathrm{b}}$ & Austria & Finland $^{\mathrm{b}}$ & Germany & Greece & Ireland $^{\mathrm{b}}$ & Italy & Spain & US & UK & Japan \\
\hline & & & & & & & & & & & \\
\hline 1990 & $\ldots$ & 0,16 & 0,16 & 0,23 & 0,17 & $\ldots$ & 0,13 & 0,21 & 0,52 & 0,84 & 0,97 \\
1991 & $\ldots$ & 0,15 & 0,11 & 0,22 & 0,13 & $\ldots$ & 0,13 & 0,23 & 0,66 & 0,93 & 0,90 \\
1992 & $\ldots$. & 0,11 & 0,11 & 0,17 & 0,10 & $\ldots$ & 0,10 & 0,16 & 0,70 & 0,85 & 0,61 \\
1993 & $\ldots$. & 0,15 & 0,27 & 0,23 & 0,13 & $\ldots$. & 0,14 & 0,23 & 0,75 & 1,17 & 0,67 \\
1994 & 0,41 & 0,15 & 0,38 & 0,23 & 0,12 & $\ldots$. & 0,18 & 0,24 & 0,70 & 1,08 & 0,75 \\
1995 & 0,45 & 0,14 & 0,34 & 0,23 & 0,13 & 0,38 & 0,19 & 0,25 & 0,92 & 1,16 & 0,67 \\
1996 & 0,54 & 0,14 & 0,49 & 0,27 & 0,17 & 0,47 & 0,20 & 0,39 & 1,07 & 1,35 & 0,65 \\
1997 & 0,65 & 0,18 & 0,60 & 0,38 & 0,25 & 0,61 & 0,29 & 0,51 & 1,27 & 1,47 & 0,51 \\
1998 & 0,90 & 0,17 & 1,18 & 0,50 & 0,60 & 0,76 & 0,46 & 0,66 & 1,43 & 1,63 & 0,63 \\
1999 & 1,13 & 0,16 & 2,68 & 0,67 & 1,43 & 0,71 & 0,61 & 0,70 & 1,78 & 1,90 & 1,02 \\
Average & 0,68 & 0,15 & 0,63 & 0,31 & 0,32 & 0,59 & 0,24 & 0,36 & 0,98 & 1,05 & 0,74 \\
2000 & 1,04 & 0,16 & 2,41 & 0,67 & 0,84 & 0,84 & 0,70 & 0,87 & 1,52 & 1,76 & 0,68 \\
2001 & 0,84 & 0,13 & 1,53 & 0,57 & 0,64 & 0,72 & 0,47 & 0,77 & 1,34 & 1,47 & 0,55 \\
2002 & 0,65 & 0,16 & 1,02 & 0,34 & 0,45 & 0,49 & 0,39 & 0,67 & 1,04 & 1,15 & 0,53 \\
2003 & 0,80 & 0,22 & 1,04 & 0,44 & 0,53 & 0,54 & 0,41 & 0,82 & 1,27 & 1,32 & 0,70 \\
2004 & 0,87 & 0,30 & $\ldots$. & 0,43 & 0,53 & 0,61 & 0,46 & 0,90 & 1,37 & 1,30 & 0,77 \\
2005 & 0,92 & 0,42 & $\ldots$. & 0,44 & 0,60 & 0,56 & 0,45 & 0,85 & 1,37 & 1,34 & 1,00 \\
2006 & 1,20 & 0,62 & $\ldots$. & 0,56 & 0,79 & 0,73 & 0,55 & 1,07 & 1,44 & 1,55 & 1,06 \\
2007 & 1,25 & 0,63 & $\ldots$. & 0,63 & 0,85 & 0,55 & 0,51 & 1,23 & 1,40 & 1,37 & 0,99 \\
2008 & 0,59 & 0,18 & $\ldots$. & 0,30 & 0,26 & 0,19 & 0,23 & 0,59 & 0,80 & 0,70 & 0,64 \\
2009 & 0,84 & 0,30 & $\ldots$. & 0,39 & 0,34 & 0,28 & 0,31 & 0,98 & 1,07 & 1,28 & 0,65 \\
2010 & 0,86 & 0,34 & $\ldots$. & 0,43 & 0,22 & 0,30 & 0,30 & 0,85 & 1,18 & 1,60 & 0,71 \\
Average & 0,90 & 0,32 & 1,66 & 0,47 & 0,55 & 0,53 & 0,43 & 0,87 & 1,25 & 1,35 & 0,75 \\
Growth \% & 31,33 & 109,20 & 162,00 & 51,41 & 70,33 & $-9,88$ & 78,29 & 143,66 & 28,03 & 28,93 & 1,94 \\
& & & & & & & & & & &
\end{tabular}

a- The figures refer to the following stock exchanges: Wiener Börse (Austria), Euronext (Brussels, Amsterdam, Paris and Lisbon), Helsinki (Finland), Deutsche Börse (Germany), Athens (Greece), Irish (Ireland), Borsa Italiana (Italy), BME Spanish (Spain), London (UK), Tokyo (Japan), NASDAQ + NYSE (US).

b- Data for Euronext and Ireland start 1994 and 1995, respectively. Data for Finland end 2003 since Finland's stock exchange merged in OMX Nordic

c- Growth refers to the percentage changes between the averages in the two subsample periods 
Table 2. Value of share traded ratio as percentage of GDP for the Euro area, the United States, the UK, and Japan, 1990-2008.

\begin{tabular}{|c|c|c|c|c|c|c|c|c|c|c|c|}
\hline & Austria & Euronext & Finland & Germany & Greece & Ireland & Italy & Spain & US & UK & Japan \\
\hline 1990 & 0,16 & 0,11 & 0,03 & 0,33 & 0,04 & $\ldots$ & 0,04 & $\ldots$ & 0,31 & 0,53 & 0,42 \\
\hline 1991 & 0,15 & 0,10 & 0,01 & 0,22 & 0,02 & $\ldots$ & 0,02 & $\ldots$ & 0,37 & 0,52 & 0,24 \\
\hline 1992 & 0,11 & 0,10 & 0,02 & 0,22 & 0,01 & $\ldots$ & 0,02 & $\ldots$ & 0,42 & 0,60 & 0,13 \\
\hline 1993 & 0,15 & 0,14 & 0,09 & 0,28 & 0,03 & $\ldots$ & 0,06 & $\ldots$ & 0,54 & 0,88 & 0,18 \\
\hline 1994 & 0,15 & 0,17 & 0,13 & 0,28 & 0,05 & $\ldots$. & 0,11 & $\ldots$ & 0,55 & 0,97 & 0,18 \\
\hline 1995 & 0,14 & 0,18 & 0,15 & 0,24 & 0,05 & $\ldots$ & 0,08 & $\ldots$ & 0,74 & 1,00 & 0,17 \\
\hline 1996 & 0,14 & 0,25 & 0,17 & 0,33 & 0,06 & 0,16 & 0,08 & $\ldots$ & 0,94 & 1,16 & 0,20 \\
\hline 1997 & 0,18 & 0,37 & 0,29 & 0,49 & 0,16 & 0,21 & 0,17 & $\ldots$ & 1,23 & 1,46 & 0,21 \\
\hline 1998 & 0,17 & 0,53 & 0,47 & 0,68 & 0,37 & 0,45 & 0,40 & $\ldots$ & 1,46 & 1,98 & 0,19 \\
\hline Average & 0,15 & 0,22 & 0,15 & 0,34 & 0,09 & 0,27 & 0,11 & & 0,73 & 1,01 & 0,21 \\
\hline 1999 & 0,16 & 0,62 & 0,84 & 0,72 & 1,37 & 0,49 & 0,45 & $\ldots$ & 2,08 & 2,26 & 0,38 \\
\hline 2000 & 0,16 & 0,85 & 1,71 & 1,11 & 0,74 & 0,15 & 0,93 & 0,89 & 3,10 & 3,08 & 0,50 \\
\hline 2001 & 0,13 & 0,93 & 1,45 & 0,75 & 0,29 & 0,22 & 0,57 & 1,07 & 2,08 & 3,07 & 0,41 \\
\hline 2002 & 0,16 & 0,83 & 1,31 & 0,60 & 0,16 & 0,27 & 0,52 & 1,42 & 1,65 & 2,48 & 0,40 \\
\hline 2003 & 0,22 & 0,74 & 1,01 & 0,53 & 0,20 & 0,28 & 0,54 & 1,28 & 1,50 & 1,94 & 0,50 \\
\hline 2004 & 0,30 & 0,88 & $\ldots$ & 0,56 & 0,19 & 0,24 & 0,56 & 1,28 & 1,72 & 2,35 & 0,70 \\
\hline 2005 & 0,42 & 0,99 & $\ldots$. & 0,69 & 0,27 & 0,33 & 0,73 & 1,63 & 1,92 & 2,49 & 0,98 \\
\hline 2006 & 0,62 & 1,25 & $\ldots \ldots$ & 0,94 & 0,41 & 0,37 & 0,85 & 1,46 & 2,51 & 3,09 & 1,33 \\
\hline 2007 & 0,63 & 1,67 & $\ldots$. & 1,30 & 0,54 & 0,53 & 1,09 & 1,67 & 4,07 & 3,67 & 1,46 \\
\hline 2008 & 0,18 & 1,25 & $\ldots$. & 1,29 & 0,32 & 0,31 & 0,65 & 2,54 & 4,88 & 2,34 & 1,15 \\
\hline Average & 0,30 & 1,00 & 1,26 & 0,85 & 0,45 & 0,29 & 0,69 & 1,47 & 2,55 & 2,68 & 0,78 \\
\hline Growth\% & 98,69 & 364,20 & 733,41 & 148,59 & 408,96 & 4,74 & 529,38 & $\ldots \ldots$ & 250,01 & 164,41 & 265,04 \\
\hline
\end{tabular}

- $\quad$ Data is limited to 2008. Data for Ireland and Spain starts 1996 and 2000, respectively. 
Table 3. Turnover ratio in the Euro area, the United States, the UK, and Japan, 1990-2008

$$
\text { Euronext Austria Finland Germany Greece Ireland Italy Spain US UK Japan }
$$

\begin{tabular}{llllllllllll}
\hline & & & & & & & & & & \\
1990 & $\ldots$ & 0,43 & $\mathbf{0 , 1 7}$ & 1,43 & 0,25 & $\ldots$ & 0,28 & $\ldots$ & 0,59 & 0,64 & 0,44 \\
1991 & $\ldots$ & 0,28 & 0,11 & 1,03 & 0,19 & $\ldots$ & 0,15 & $\ldots$ & 0,56 & 0,56 & 0,26 \\
1992 & $\ldots$ & 0,24 & 0,18 & 1,31 & 0,15 & $\ldots$ & 0,22 & $\ldots$ & 0,60 & 0,71 & 0,21 \\
1993 & $\ldots$ & 0,26 & 0,33 & 1,22 & 0,20 & $\ldots$ & 0,45 & $\ldots$ & 0,73 & 0,75 & 0,27 \\
1994 & 0,41 & 0,28 & 0,35 & 1,19 & 0,40 & $\ldots$ & 0,64 & $\ldots$ & 0,79 & 0,90 & 0,24 \\
1995 & 0,40 & 0,41 & 0,44 & 1,03 & 0,37 & $\ldots$. & 0,42 & $\ldots$. & 0,80 & 0,86 & 0,25 \\
1996 & 0,46 & 0,32 & 0,35 & 1,22 & 0,35 & 0,34 & 0,40 & $\ldots$. & 0,88 & 0,86 & 0,31 \\
1997 & 0,57 & 0,34 & 0,49 & 1,29 & 0,63 & 0,35 & 0,59 & $\ldots$. & 0,97 & 1,00 & 0,41 \\
1998 & 0,58 & 0,53 & 0,40 & 1,37 & 0,62 & 0,60 & 0,86 & $\ldots$ & 1,02 & 1,22 & 0,31 \\
Average & 0,48 & 0,34 & 0,31 & 1,23 & 0,35 & 0,43 & 0,45 & $\ldots$ & 0,77 & 0,83 & 0,30 \\
1999 & 0,55 & 0,39 & 0,31 & 1,08 & 0,96 & 0,69 & 0,74 & $\ldots$. & 1,17 & 1,19 & 0,38 \\
2000 & 0,81 & 0,32 & 0,71 & 1,67 & 0,88 & 0,18 & 1,33 & 0,89 & 2,04 & 1,75 & 0,73 \\
2001 & 1,11 & 0,31 & 0,95 & 1,33 & 0,45 & 0,30 & 1,20 & 1,07 & 1,55 & 2,09 & 0,73 \\
2002 & 1,28 & 0,18 & 1,28 & 1,77 & 0,36 & 0,56 & 1,33 & 1,42 & 1,59 & 2,16 & 0,76 \\
2003 & 0,93 & 0,20 & 0,97 & 1,20 & 0,38 & 0,52 & 1,33 & 1,28 & 1,18 & 1,47 & 0,71 \\
2004 & 1,01 & 0,28 & $\ldots$. & 1,29 & 0,36 & 0,40 & 1,23 & 1,28 & 1,25 & 1,80 & 0,90 \\
2005 & 1,07 & 0,37 & $\ldots$. & 1,57 & 0,45 & 0,59 & 1,62 & 1,63 & 1,40 & 1,86 & 0,98 \\
2006 & 1,04 & 0,41 & $\ldots$. & 1,67 & 0,52 & 0,50 & 1,55 & 1,46 & 1,74 & 2,00 & 1,26 \\
2007 & 1,34 & 0,55 & $\ldots$. & 2,05 & 0,64 & 0,95 & 2,15 & 1,67 & 2,91 & 2,68 & 1,48 \\
2008 & 2,13 & 1,37 & $\ldots$. & 4,23 & 1,26 & 1,66 & 2,87 & 2,54 & 6,11 & 3,36 & 1,80 \\
Average & 1,13 & 0,44 & 0,85 & 1,79 & 0,63 & 0,63 & 1,54 & 1,47 & 2,09 & 2,03 & 0,97 \\
Growth\% & 134,00 & 27,70 & 169,93 & 44,88 & 77,94 & 47,55 & 244,20 & $\ldots$ & 171,92 & 144,21 & 223,99 \\
& & & & & & & & & & & \\
\hline
\end{tabular}

- $\quad$ Data is limited to 2008 . 
Table 4. Average daily trading in the Euro area, the United States, the UK, and Japan, 1990-2010 ${ }^{\text {a }}$

Euronext Austria Finland Germany Greece Ireland Italy Spain US UK Japan

\begin{tabular}{llllllllllll}
\hline & & & & & & & & & & & \\
1990 & 0,67 & 0,04 & 0,02 & 2,00 & 0,02 & $\ldots$ & 0,17 & $\ldots$ & 7,05 & 2,16 & 5,26 \\
1991 & 0,64 & 0,03 & 0,01 & 1,59 & 0,01 & $\ldots$ & 0,09 & $\ldots$ & 8,79 & 2,20 & 3,36 \\
1992 & 0,70 & 0,02 & 0,01 & 1,79 & 0,01 & $\ldots$. & 0,11 & $\ldots$ & 10,46 & 2,63 & 1,95 \\
1993 & 0,99 & 0,03 & 0,03 & 2,22 & 0,01 & $\ldots$. & 0,26 & $\ldots$ & 14,42 & 3,44 & 3,24 \\
1994 & 1,21 & 0,03 & 0,05 & 2,33 & 0,02 & $\ldots$ & 0,47 & $\ldots$ & 15,49 & 4,08 & 3,51 \\
1995 & 1,41 & 0,05 & 0,08 & 2,34 & 0,02 & $\ldots$ & 0,34 & $\ldots$ & 21,75 & 4,58 & 3,61 \\
1996 & 1,98 & 0,04 & 0,09 & 3,20 & 0,03 & 0,05 & 0,41 & $\ldots$ & 29,23 & 5,61 & 3,83 \\
1997 & 2,92 & 0,05 & 0,14 & 4,20 & 0,08 & 0,07 & 0,80 & $\ldots$ & 40,71 & 7,89 & 3,66 \\
1998 & 4,33 & 0,07 & 0,24 & 5,87 & 0,20 & 0,16 & 1,92 & $\ldots$ & 50,94 & 11,46 & 3,06 \\
Average & 1,65 & 0,04 & 0,07 & 2,84 & 0,05 & 0,09 & 0,51 & & 22,09 & 4,89 & 3,50 \\
1999 & 5,24 & 0,05 & 0,44 & 6,11 & 0,76 & 0,19 & 2,13 & $\ldots$. & 77,03 & 13,49 & 6,84 \\
2000 & 7,20 & 0,04 & 0,83 & 8,35 & 0,38 & 0,06 & 4,03 & 1,78 & 122,46 & 18,09 & 9,45 \\
2001 & 8,17 & 0,03 & 0,72 & 5,60 & 0,15 & 0,09 & 2,51 & 1,98 & 85,01 & 17,94 & 6,78 \\
2002 & 7,74 & 0,02 & 0,72 & 4,79 & 0,09 & 0,13 & 2,52 & 2,61 & 69,70 & 15,88 & 6,36 \\
2003 & 7,59 & 0,04 & 0,66 & 5,14 & 0,16 & 0,17 & 3,26 & 3,73 & 66,51 & 14,27 & 8,61 \\
2004 & 9,54 & 0,10 & $\ldots$. & 6,00 & 0,18 & 0,18 & 3,77 & 4,79 & 80,89 & 20,35 & 13,08 \\
2005 & 11,31 & 0,19 & $\ldots$. & 7,45 & 0,26 & 0,27 & 5,05 & 6,14 & 96,08 & 22,53 & 18,29 \\
2006 & 15,11 & 0,33 & $\ldots$. & 10,82 & 0,43 & 0,32 & 6,26 & 7,58 & 133,85 & 30,05 & 23,48 \\
2007 & 22,03 & 0,53 & $\ldots$ & 17,16 & 0,67 & 0,54 & 9,17 & 11,69 & 228,01 & 40,68 & 26,17 \\
2008 & 17,49 & 0,42 & $\ldots$. & 18,49 & 0,46 & 0,32 & 5,93 & 9,49 & 277,02 & 24,69 & 22,89 \\
Average & 11,14 & 0,17 & 0,67 & 8,99 & 0,35 & 0,23 & 4,46 & 5,53 & 123,66 & 21,80 & 14,19 \\
Growth\% & 575,62 & 317,75 & 810,14 & 216,75 & 683,89 & 149,78 & 777,43 & $\ldots$ & 459,70 & 345,38 & 305,94 \\
& & & & & & & & & & & \\
\hline
\end{tabular}

a- See the text below table 1 . 
Table 5. Market concentration of the $5 \%$ of the largest companies by market value in the Euro area, the United States, the UK, and Japan; 1995-201

\begin{tabular}{|c|c|c|c|c|c|c|c|c|c|c|c|c|}
\hline$\%$ & Austria & Finland & Germany & Greece & Ireland & Italy & Spain & Euronext & EMU & US & UK & Japan \\
\hline 1995 & 0,34 & 0,43 & 0,67 & 0,43 & 0,48 & 0,56 & 0,65 & 0,57 & 0,52 & 0,54 & 0,72 & 0,50 \\
\hline 1996 & 0,37 & 0,28 & 0,72 & 0,64 & 0,46 & 0,63 & 0,66 & 0,56 & 0,54 & 0,57 & 0,72 & 0,52 \\
\hline 1997 & 0,38 & 0,29 & 0,73 & 0,66 & 0,52 & 0,61 & 0,70 & 0,58 & 0,56 & 0,61 & 0,76 & 0,60 \\
\hline 1998 & 0,37 & 0,48 & 0,78 & 0,63 & 0,64 & 0,60 & 0,65 & 0,63 & 0,60 & 0,74 & 0,81 & 0,58 \\
\hline Average & 0,37 & 0,37 & 0,73 & 0,59 & 0,53 & 0,60 & 0,67 & 0,59 & 0,55 & 0,62 & 0,75 & 0,55 \\
\hline 1999 & 0,40 & 0,60 & 0,79 & 0,39 & 0,52 & 0,61 & 0,80 & 0,66 & 0,60 & 0,71 & 0,79 & 0,69 \\
\hline 2000 & 0,40 & 0,88 & 0,68 & 0,52 & 0,61 & 0,61 & 0,81 & 0,78 & 0,66 & 0,67 & 0,81 & 0,64 \\
\hline 2001 & 0,38 & 0,84 & 0,66 & 0,57 & 0,55 & 0,63 & 0,73 & 0,76 & 0,64 & 0,68 & 0,84 & 0,62 \\
\hline 2002 & 0,47 & 0,77 & 0,72 & 0,60 & 0,60 & 0,66 & 0,74 & 0,70 & 0,66 & 0,64 & 0,85 & 0,61 \\
\hline 2003 & 0,50 & 0,74 & 0,72 & 0,61 & 0,55 & 0,62 & 0,74 & 0,70 & 0,65 & 0,64 & 0,82 & 0,58 \\
\hline 2004 & 0,62 & 0,70 & 0,73 & 0,73 & 0,51 & 0,62 & $\ldots \ldots$ & 0,69 & 0,58 & 0,58 & 0,82 & 0,57 \\
\hline 2005 & 0,54 & 0,67 & 0,73 & 0,72 & 0,43 & 0,61 & $\ldots \ldots$ & 0,68 & 0,55 & 0,57 & 0,86 & 0,56 \\
\hline 2006 & 0,50 & 0,67 & 0,75 & 0,67 & 0,47 & 0,60 & $\ldots \ldots$ & 0,66 & 0,54 & 0,55 & 0,84 & 0,61 \\
\hline 2007 & 0,48 & 0,69 & 0,78 & 0,73 & 0,43 & 0,67 & $\ldots \ldots$ & 0,68 & 0,56 & 0,61 & 0,86 & 0,62 \\
\hline 2008 & 0,48 & 0,75 & 0,81 & 0,69 & 0,58 & 0,68 & $\ldots \ldots$ & 0,69 & 0,59 & 0,64 & 0,89 & 0,60 \\
\hline 2009 & 0,49 & 0,71 & 0,80 & 0,67 & 0,51 & 0,70 & $\ldots \ldots$ & 0,70 & 0,57 & 0,61 & 0,86 & 0,60 \\
\hline 2010 & 0,49 & 0,70 & 0,78 & 0,72 & 0,47 & 0,72 & $\ldots \ldots$ & 0,69 & 0,57 & 0,64 & 0,82 & 0,60 \\
\hline Average & 0,48 & 0,73 & 0,75 & 0,64 & 0,52 & 0,64 & 0,76 & 0,70 & 0,60 & 0,63 & 0,84 & 0,61 \\
\hline Changes\% & 23,83 & 49,08 & 2,79 & 7,09 & $-1,12$ & 6,86 & 12,96 & 16,10 & 7,15 & 2,12 & 10,24 & 9,59 \\
\hline
\end{tabular}

- $\quad$ EMU refers to the average of the 11 EMU countries. 
Table 6. Descriptive statistics on monthly stock returns in the Euro area, the United Sates, the UK, and Japan over two subsamples 1990(2)-1998(12) and 1999(1)-2010(12). ${ }^{\mathrm{a}}$

\begin{tabular}{|c|c|c|c|c|c|c|c|c|c|c|}
\hline & \multicolumn{4}{|c|}{ Pre Euro } & \multicolumn{4}{|c|}{ Post Euro } & \multicolumn{2}{|c|}{$\begin{array}{l}\text { Variance of the } \\
\text { fitted values }\end{array}$} \\
\hline & Mean & SD & Skewness & $\begin{array}{l}\text { Excess } \\
\text { Kurtosis }\end{array}$ & Mean & $\mathrm{SD}$ & Skewness & $\begin{array}{l}\text { Excess } \\
\text { Kurtosis }\end{array}$ & $\begin{array}{l}\text { Pre } \\
\text { Euro }\end{array}$ & $\begin{array}{l}\text { Post } \\
\text { Euro }\end{array}$ \\
\hline Austria & $-0,15$ & 6,39 & $-0,84$ & 3,17 & 0,38 & 11,26 & $-1,90$ & 8,20 & 0,25 & 0,53 \\
\hline Belgium & 2,46 & 8,50 & 0,03 & 3,21 & $-0,78$ & 18,01 & $-1,89$ & 4,92 & 0,42 & 0,96 \\
\hline Finland & 4,58 & 20,62 & $-0,36$ & 8,50 & 0,05 & 96,85 & $-0,02$ & 4,59 & 4,20 & 17,89 \\
\hline France & 1,59 & 9,11 & $-0,58$ & 3,01 & 0,55 & 17,68 & $-0,66$ & 0,81 & 0,65 & 1,31 \\
\hline Germany & 1,45 & 9,30 & $-1,62$ & 8,97 & 0,56 & 17,01 & $-0,56$ & 1,40 & 0,75 & 1,47 \\
\hline Greece & $\ldots$ & $\ldots$ & $\ldots$ & $\ldots$ & $-0,50$ & 7,27 & $-1,32$ & 3,30 & 3,30 & 0,56 \\
\hline Ireland & 1,83 & 8,67 & $-0,49$ & 5,83 & $-1,38$ & 14,83 & $-0,68$ & 0,52 & 0,76 & 1,40 \\
\hline Italy & 1,64 & 10,87 & 0,42 & 4,13 & $-0,41$ & 14,85 & $-0,28$ & 0,67 & 0,82 & 1,20 \\
\hline Netherlands & 3,27 & 14,14 & $-1,03$ & 6,95 & 0,04 & 24,95 & $-0,93$ & 1,37 & 1,48 & 1,97 \\
\hline Portugal & 1,41 & 9,93 & $-0,40$ & 4,83 & $-0,19$ & 12,79 & $-0,53$ & 1,99 & 0,59 & 0,99 \\
\hline Spain & 3,31 & 17,59 & $-1,77$ & 15,86 & 1,57 & 36,06 & $-0,63$ & 2,08 & 0,55 & 1,62 \\
\hline $\mathrm{EMU}^{\mathrm{a}}$ & 1,89 & 9,51 & $-1,31$ & 7,58 & 0,29 & 18,18 & $-0,64$ & 1,27 & 0,73 & 1,27 \\
\hline US & 3,41 & 10,52 & $-1,34$ & 9,91 & 0,64 & 20,98 & $-0,63$ & 0,85 & 0,33 & 0,73 \\
\hline UK & 2,22 & 7,90 & $-0,43$ & 2,95 & 1,12 & 15,74 & $-0,73$ & 0,83 & 0,12 & 0,26 \\
\hline Japan & $-0,49$ & 4,08 & $-0,41$ & 1,18 & $-0,04$ & 2,76 & $-0,42$ & 1,17 & 0,29 & 0,24 \\
\hline
\end{tabular}

a- The figures are averages. All returns are net and are denominated in local currency. We follow a two-step estimation procedure.

b- As in Schwert, 1989, and Levine and Zervos, 1996, we first estimate a $12^{\text {th }}$ order autoregression of monthly returns, $\mathrm{R}_{\mathrm{t}}$, including dummy variables, $\mathrm{D}_{\mathrm{it}}$ to allow for different monthly mean return: $R_{t}=\sum_{i=1}^{12} a_{i} D_{i t}+$ $\sum_{k=1}^{12} b_{k} R_{t-k}+v_{t}$. We collect the absolute value of the residual $\left(\mathrm{v}_{\mathrm{t}}\right)$, and then estimate a $12^{\text {th }}$-order autoregression of the absolute value of the residuals including dummy variables for each month to allow for different monthly standard deviations of returns: $v=\sum_{i=1}^{12} c_{i} D_{i t}+\sum_{k=1}^{12} d_{t}$. The fitted values from the last equation give estimates of the conditional standard deviation of return. 
Table 7. Variance equality tests of returns in the Euro area, the United States, the UK, and Japan over the two subsample periods.

$\mathrm{H}_{0}: \sigma_{\text {pre }}^{2}=\sigma_{\text {post }}^{2} \quad \sigma_{\text {pre }}^{2} \quad \sigma_{\text {post }}^{2} \quad$ F-test $\quad$ Probability (Note 10)

\begin{tabular}{lllll}
\hline Austria & 41,19 & 127,54 & 0,32 & 0,000 \\
Belgium & 72,88 & 326,51 & 0,22 & 0,000 \\
Finland & 429,31 & 9443,23 & 0,05 & 0,000 \\
France & 83,79 & 314,54 & 0,27 & 0,000 \\
Germany & 87,31 & 291,33 & 0,30 & 0,000 \\
Greece & 27,6 & 78,4 & 0,34 & 0,000 \\
Ireland & 75,95 & 221,38 & 0,34 & 0,000 \\
Italy & 119,35 & 221,98 & 0,54 & 0,000 \\
Netherlands & 201,74 & 626,52 & 0,32 & 0,000 \\
Portugal & 99,60 & 164,70 & 0,60 & 0,003 \\
Spain & 312,39 & 1309,25 & 0,24 & 0,000 \\
EMU & 91,39 & 332,76 & 0,27 & 0,000 \\
US & 11,72 & 442,97 & 0,25 & 0,000 \\
UK & 62,96 & 249,28 & 0,25 & 0,000 \\
Japan & 16,78 & 7,68 & 2,18 & 0,000 \\
& & & &
\end{tabular}

Table 8. likelihood estimation of ARFIMA $(1,0,1)$ and $(1, \mathrm{~d}, 1)$ model of the Euro zone returns between 1990(2)-2010(10) (Note 11)

\begin{tabular}{|c|c|c|c|c|c|c|c|c|c|c|c|c|c|c|c|}
\hline & $\alpha_{1}$ & $\beta_{1}$ & $\gamma_{0}$ & $\Lambda$ & Normality & $\mathrm{ARCH}$ & $\mathrm{Q}(34)$ & $\alpha_{1}$ & $\beta_{1}$ & $\gamma_{0}$ & $\Lambda$ & $\mathrm{d}$ & Normality & $\mathrm{ARCH}$ & $Q(36)$ \\
\hline \multirow[t]{2}{*}{ Austria } & 0,58 & $-0,4$ & $-0,1$ & 0,42 & 78,25 & 11,89 & 37,13 & 0,95 & 0 & 0,08 & 0,45 & $-0,8$ & 93,88 & 12,56 & 37,14 \\
\hline & 0,18 & 0,21 & 1,33 & 1,74 & {$[0,00]^{* *}$} & {$[0,00]^{* *}$} & {$[0,32]$} & 0,04 & 0,13 & 0,76 & 1,13 & 0,14 & {$[0,00]^{* *}$} & {$[0,00]^{* *}$} & {$[0,28]$} \\
\hline \multirow[t]{2}{*}{ Belgium } & 0,17 & 0,05 & 2,52 & $-3,4$ & 117,06 & 11,41 & 46,67 & $-0,07$ & 0,18 & 2,76 & -4 & 0,1 & 107,68 & 10,31 & 42,67 \\
\hline & 0,25 & 0,25 & 1,76 & 2,3 & {$[0,00]^{* *}$} & {$[0,00]^{* *}$} & {$[0,07]$} & 0,32 & 0,29 & 2,4 & 2,92 & 0,08 & {$[0,00]^{* *}$} & {$[0,00]^{* *}$} & {$[0,12]$} \\
\hline \multirow[t]{2}{*}{ Finland } & 0,13 & 0,17 & 4,49 & $-4,5$ & 156,56 & 44,97 & 52,56 & 0,18 & 0,15 & 4,76 & $-4,8$ & 0 & 156,5 & 45,75 & 52,71 \\
\hline & 0,19 & 0,19 & 9,35 & 12,1 & {$[0,00]^{* *}$} & {$[0,00]^{* *}$} & {$[0,02]^{*}$} & 0,33 & 0,23 & 8,75 & 11,57 & 0,14 & {$[0,00]^{* *}$} & {$[0,00]^{* *}$} & {$[0,01]^{*}$} \\
\hline \multirow[t]{2}{*}{ France } & 0,83 & $-0,7$ & 1,48 & -1 & 20,25 & 3,07 & 28,71 & $-0,37$ & 0,41 & 1,43 & $-0,9$ & 0,08 & 21,45 & 2,53 & 32,04 \\
\hline & 0,13 & 0,16 & 2,06 & 2,68 & {$[0,00]^{* *}$} & {$[0,08]$} & {$[0,72]$} & 0,56 & 0,53 & 2,07 & 2,57 & 0,07 & {$[0,00]^{* *}$} & {$[0,11]$} & {$[0,51]$} \\
\hline \multirow[t]{2}{*}{ Germany } & 0,74 & $-0,7$ & 1,43 & $-0,9$ & 34,86 & 1,2 & 32,18 & 0,93 & $-0,1$ & 1,5 & $-0,9$ & $-0,8$ & 36,57 & 1,24 & 32,08 \\
\hline & 0,26 & 0,29 & 1,77 & 2,3 & {$[0,00]^{* *}$} & {$[0,27]$} & {$[0,55]$} & 0,04 & 0,15 & 0,78 & 1,17 & 0,16 & {$[0,00]^{* *}$} & {$[0,26]$} & {$[0,51]$} \\
\hline \multirow[t]{2}{*}{ Greece } & 0,8 & $-0,7$ & & $-0,5$ & 27,7 & 0 & 30,48 & $-0,2$ & 0,26 & & $-0,6$ & 0,09 & 30,98 & 0 & 32,83 \\
\hline & 0,22 & 0,27 & & 0,96 & {$[0,00]^{* *}$} & {$[0,96]$} & {$[0,64]$} & 0,8 & 0,75 & & 1,03 & 0,1 & {$[0,00]^{* *}$} & {$[0,98]$} & {$[0,47]$} \\
\hline \multirow[t]{2}{*}{ Ireland } & 0,36 & $-0,1$ & 1,84 & $-3,3$ & 19,4 & 10,96 & 43,91 & 0,04 & 0,08 & 1,77 & $-3,3$ & 0,1 & 20,56 & 10,95 & 42,16 \\
\hline & 0,28 & 0,3 & 1,6 & 2,08 & {$[0,001]^{* *}$} & {$[0,00]^{* *}$} & {$[0,11]$} & 0,58 & 0,52 & 2,05 & 2,51 & 0,1 & {$[0,00]^{* *}$} & {$[0,00]^{* *}$} & {$[0,13]$} \\
\hline \multirow[t]{2}{*}{ Italy } & 0,88 & $-0,8$ & 1,66 & $-2,2$ & 20,7 & 2,79 & 38,31 & 0,11 & $-0,2$ & 1,62 & $-2,3$ & 0,13 & 21,18 & 2,42 & 36,48 \\
\hline & 0,1 & 0,12 & 1,72 & 2,23 & {$[0,00]^{* *}$} & {$[0,09]$} & {$[0,28]$} & 0,34 & 0,38 & 1,98 & 2,35 & 0,12 & {$[0,00]^{* *}$} & {$[0,12]$} & {$[0,31]$} \\
\hline \multirow[t]{2}{*}{ Netherlands } & 0,82 & $-0,8$ & 3,23 & $-3,3$ & 31,13 & 13,55 & 38,38 & 0,24 & $-0,2$ & 3,25 & $-3,3$ & 0,05 & 32,61 & 13,06 & 39,89 \\
\hline & 0,16 & 0,18 & 2,65 & 3,45 & {$[0,00]^{* *}$} & {$[0,00]^{* *}$} & {$[0,27]$} & 1,22 & 1,14 & 2,61 & 3,3 & 0,14 & {$[0,00]^{* *}$} & {$[0,00]^{* *}$} & {$[0,19]$} \\
\hline \multirow[t]{2}{*}{ Portugal } & $-0,1$ & 0,25 & 1,38 & $-1,6$ & 47,4 & 9,02 & 44,38 & $-0,96$ & 1 & 1,3 & $-1,6$ & 0,1 & 32,61 & 13,06 & 39,89 \\
\hline & 0,61 & 0,59 & 1,27 & 1,66 & {$[0,00]^{* *}$} & {$[0,00]^{* *}$} & {$[0,10]$} & 0,02 & 0,01 & 1,79 & 2,17 & 0,05 & {$[0,00]^{* *}$} & {$[0,00]^{* *}$} & {$[0,19]$} \\
\hline \multirow[t]{2}{*}{ Spain } & $-0,5$ & 0,61 & 3,32 & $-1,8$ & 53,41 & 0,12 & 32,14 & $-0,34$ & 0,53 & 3,31 & $-1,6$ & $-0,1$ & 51,87 & 0,11 & 30,28 \\
\hline & 0,26 & 0,24 & 3,13 & 4,09 & {$[0,00]^{* *}$} & {$[0,72]$} & {$[0,55]$} & 0,28 & 0,22 & 2,58 & 3,46 & 0,07 & {$[0,00]^{* *}$} & {$[0,74]$} & {$[0,60]$} \\
\hline \multirow[t]{2}{*}{ EMU } & 0,8 & $-0,7$ & 1,87 & $-1,7$ & 30,47 & 12,25 & 37,92 & 0,27 & $-0,2$ & 1,82 & $-1,6$ & 0,09 & 30,55 & 3,54 & 31,16 \\
\hline & 0,16 & 0,19 & 2,1 & 2,74 & {$[0,00]^{* *}$} & {$[0,00]^{* *}$} & {$[0,29]$} & 0,81 & 0,74 & 2,21 & 2,73 & 0,14 & {$[0,00]^{* *}$} & {$[0,06]$} & {$[0,55]$} \\
\hline \multirow[t]{2}{*}{ US } & $-0,6$ & 0,73 & 1,78 & & 24,63 & 11,63 & 33,16 & $-0,69$ & 0,78 & 1,78 & & 0,04 & 24,33 & 12,44 & 30,77 \\
\hline & 0,22 & 0,19 & 1,15 & & {$[0,00]^{* *}$} & {$[0,00]^{* *}$} & {$[0,50]$} & 0,23 & 0,19 & 1,41 & & 0,06 & {$[0,00]^{* *}$} & {$[0,00]^{* *}$} & {$[0,57]$} \\
\hline \multirow[t]{2}{*}{ UK } & $-0,2$ & 0,29 & 1,57 & & 26,01 & 12,25 & 37,92 & $-0,2$ & 0,27 & 1,57 & & 26,3 & 26,3 & 12,21 & 37,81 \\
\hline & 0,4 & 0,39 & 0,85 & & {$[0,00]^{* *}$} & {$[0,00]^{* *}$} & {$[0,29]$} & 0,41 & 0,38 & 0,81 & & {$[0,00]^{* *}$} & {$[0,00]^{* *}$} & {$[0,00]^{* *}$} & {$[0,25]$} \\
\hline \multirow[t]{2}{*}{ Japan } & 0,12 & 0 & $-0,2$ & & 20,4 & 31,36 & 17,45 & 0,11 & 0 & $-0,2$ & & 0,01 & 20,7 & 30,71 & 17,39 \\
\hline & 1,53 & 1,53 & 0,23 & & {$[0,00]^{* *}$} & {$[0,00]^{* *}$} & {$[0,99]$} & 1,01 & 0,94 & 0,24 & & 0,13 & {$[0,00]^{* *}$} & {$[0,00]^{* *}$} & {$[0,98]$} \\
\hline
\end{tabular}


Table 9. Modeling returns by restricted GARCH $(1,1)$ with Student t-distribution errors in the Euro area, the United States, the UK, and Japan

\begin{tabular}{|c|c|c|c|c|c|c|c|c|c|c|c|c|c|c|c|}
\hline \multirow[t]{2}{*}{$\gamma_{0}$} & 0,14 & 1,27 & 1,79 & 1,07 & 1,04 & $-0,05$ & 1,47 & 0,53 & 1,74 & 0,13 & 1,71 & 1,07 & 1,95 & 2,38 & $-0,06$ \\
\hline & 0,43 & 0,51 & 1,07 & 0,62 & 0,53 & 0,29 & 0,54 & 0,72 & 0,58 & 0,47 & 0,79 & 0,52 & 0,51 & 0,57 & 0,19 \\
\hline \multirow[t]{2}{*}{$\alpha_{0}$} & 1,57 & 4,35 & 14,37 & 2,81 & 2,20 & 2,78 & 1,89 & 2,80 & 2,57 & 2,84 & 6,74 & 2,22 & 1,57 & 2,78 & 0,75 \\
\hline & 1,05 & 2,77 & 7,78 & 1,83 & 1,42 & 2,19 & 1,15 & 2,02 & 1,80 & 2,02 & 4,71 & 1,40 & 1,02 & 1,68 & 0,78 \\
\hline$\alpha_{1}$ & $\begin{array}{l}0,22 \\
(0,07)\end{array}$ & $\begin{array}{l}0,34 \\
(0,08)\end{array}$ & 0,37 & 0,23 & $\begin{array}{l}0,22 \\
(0,06)\end{array}$ & $\begin{array}{l}0,09 \\
(0,06)\end{array}$ & $\begin{array}{l}0,26 \\
(0,07)\end{array}$ & 0,21 & $\begin{array}{l}0,30 \\
(0,70)\end{array}$ & $\begin{array}{l}0,35 \\
(0,11)\end{array}$ & 0,25 & $\begin{array}{l}0,26 \\
(0,74)\end{array}$ & $\begin{array}{l}0,21 \\
(0,04)\end{array}$ & $\begin{array}{l}0,27 \\
(0,06)\end{array}$ & $\begin{array}{l}0,12 \\
(0,07)\end{array}$ \\
\hline \multirow[t]{2}{*}{$\beta_{1}$} & 0,76 & 0,66 & 0,63 & 0,77 & 0,78 & 0,85 & 0,74 & 0,79 & 0,06 & 0,65 & 0,75 & 0,06 & 0,79 & 0,73 & 0,81 \\
\hline & 0,06 & 0,08 & 0,05 & 0,05 & 0,06 & 0,07 & 0,06 & 0,06 & & 0,11 & 0,06 & & 0,04 & 0,06 & 0,13 \\
\hline \multirow[t]{2}{*}{$\lambda$} & 0,56 & $20,89^{*}$ & $45,8^{*}$ & $8,08^{*}$ & 10,06 & 0,04 & 3,50 & 5,05 & $33,57^{*}$ & $13,69^{*}$ & $81,89^{*}$ & $13,36^{*}$ & & & \\
\hline & 1,31 & 13,36 & 124 & 6,82 & 8,01 & 2,20 & 4,64 & 5,36 & 21,15 & 9,99 & 57,45 & 10,01 & & & \\
\hline \multirow[t]{2}{*}{ Student-t } & 6,87 & 4,76 & 6,21 & 9,69 & 5,46 & 6,12 & 16,28 & 11,95 & 9,19 & 4,98 & 4,35 & 7,29 & 14,60 & 10,69 & 11,09 \\
\hline & 2,93 & 1,62 & 2,58 & 5,38 & 1,77 & 2,95 & 15,46 & 7,90 & 4,70 & 1,62 & 1,36 & 3,18 & 9,29 & 6,83 & 7,09 \\
\hline Log-likelihood & -859 & -977 & -1299 & -1008 & -990 & -420 & -964 & -1002 & -1072 & -942 & -1149 & -999 & -1025 & -975 & -660 \\
\hline \multirow[t]{2}{*}{ Normality } & 11,05 & 15,99 & 9,05 & 12,75 & 43,38 & 16,44 & 2,77 & 7,97 & 14,78 & 17,24 & 25,73 & 20,35 & 14,74 & 10,11 & 5,97 \\
\hline & {$[0,004]$} & {$[0,000]$} & {$[0,01]$} & {$[0,001]$} & {$[0,00]$} & {$[0,00]$} & {$[0,25]$} & {$[0,018]$} & {$[0,000]$} & {$[0,000]$} & {$[0,000]$} & {$[0,000]$} & {$[0,000]$} & {$[0,006]$} & {$[0,05]$} \\
\hline \multirow[t]{2}{*}{$\mathrm{ARCH}$} & 0,34 & 0,17 & 0,13 & 0,53 & 0,05 & 0,31 & 0,41 & 1,20 & 0,01 & 0,43 & 1,00 & 0,04 & 0,87 & 1,04 & 0,05 \\
\hline & {$[0,71]$} & {$[0,84]$} & {$[0,87]$} & {$[0,59]$} & {$[0,95]$} & {$[0,73]$} & {$[0,66]$} & {$[0,30]$} & {$[0,98]$} & {$[0,65]$} & {$[0,37]$} & {$[0,96]$} & {$[0,42]$} & {$[0,35]$} & {$[0,95]$} \\
\hline \multirow[t]{2}{*}{$\mathrm{Q}(36)$} & 32,00 & 40,24 & 47,21 & 27,15 & 31,21 & 32,98 & 36,35 & 39,83 & 29,01 & 53,26 & 33,76 & 26,92 & 23,33 & 22,95 & 19,99 \\
\hline & {$[0,65]$} & {$[0,28]$} & {$[0,10]$} & {$[0,85]$} & {$[0,69]$} & {$[0,61]$} & {$[0,45]$} & {$[0,30]$} & {$[0,78]$} & {$[0,03]$} & {$[0,57]$} & {$[0,86]$} & {$[0,94]$} & {$[0,95]$} & {$[0,98]$} \\
\hline
\end{tabular}

The table reports the estimated parameters for the t-GARCH $(1,1)$ models. Q (36) is the Ljung-Box test for serial correlation up to the 36th order in the standardized residuals. Normality is the Bera-Jarque Normality test. Standard errors are in brackets. Bollerslev and Ghysels (1994) consider a GARCH $(1,1)$ model where a dummy variable enters the variance equation. 
Table 10. Correlations of stock market indicators in the Euro area, the United States, the UK, and Japan

\begin{tabular}{|c|c|c|c|c|c|c|c|}
\hline & & $\begin{array}{l}\text { Market } \\
\text { Capitalization } \\
\text { Ratio }\end{array}$ & $\begin{array}{l}\text { Turnover } \\
\text { Ratio }\end{array}$ & $\begin{array}{l}\text { Value } \\
\text { of Share } \\
\text { Trading }\end{array}$ & $\begin{array}{l}\text { Average } \\
\text { Daily } \\
\text { Trading }\end{array}$ & $\begin{array}{l}\text { Standard } \\
\text { Deviation }\end{array}$ & Concentration \\
\hline \multirow{4}{*}{$\begin{array}{l}\text { arket } \\
\text { apitalization Ratio }\end{array}$} & EMU & 1 & $-0,69$ & 0,65 & 0,5 & $-0,43$ & $-0,1$ \\
\hline & US & 1 & $-0,68$ & $-0,04$ & $-0,13$ & $-0,45$ & 0,1 \\
\hline & UK & 1 & $-0,62$ & 0,6 & 0,6 & $-0,55$ & $-0,4$ \\
\hline & Japan & 1 & $-0,58$ & 0,6 & 0,56 & $-0,35$ & 0,42 \\
\hline \multirow{4}{*}{$\begin{array}{l}\text { alue of Share } \\
\text { ading }\end{array}$} & EMU & & 1 & $-0,04$ & $-0,28$ & 0,74 & 0,38 \\
\hline & US & & 1 & 0,61 & 0,65 & 0,69 & 0,14 \\
\hline & UK & & 1 & 0,16 & 0,01 & 0,56 & 0,55 \\
\hline & Japan & & 1 & 0,08 & 0,22 & 0,4 & 0 \\
\hline \multirow[t]{4}{*}{ Irnover Ratio } & EMU & & & 1 & 0,57 & 0,1 & 0,24 \\
\hline & US & & & 1 & 0,98 & 0,5 & 0,14 \\
\hline & UK & & & 1 & 0,91 & $-0,33$ & 0,04 \\
\hline & Japan & & & 1 & 0,96 & $-0,45$ & 0,3 \\
\hline \multirow{4}{*}{$\begin{array}{l}\text { verage Daily } \\
\text { ading }\end{array}$} & EMU & & & & 1 & $-0,26$ & $-0,1$ \\
\hline & US & & & & 1 & 0,49 & 0,15 \\
\hline & UK & & & & 1 & $-0,48$ & $-0,1$ \\
\hline & Japan & & & & 1 & $-0,3$ & 0,24 \\
\hline \multirow[t]{4}{*}{ andard Deviation } & EMU & & & & & 1 & 0,3 \\
\hline & US & & & & & 1 & 0,61 \\
\hline & UK & & & & & 1 & 0,62 \\
\hline & Japan & & & & & 1 & $-0,12$ \\
\hline \multirow{4}{*}{ oncentration } & EMU & & & & & & 1 \\
\hline & US & & & & & & 1 \\
\hline & UK & & & & & & 1 \\
\hline & Japan & & & & & & 1 \\
\hline
\end{tabular}

Table 11. Stock Market Development Aggregate Indexes, averaging over stock market indicators

\begin{tabular}{llllll}
\hline \multicolumn{7}{l}{ Pre Euro } & \multicolumn{3}{l}{ Post Euro } & & Growth & \\
& & & & & \\
\hline US & 7,06 & US & 8,72 & US & 1,66 \\
UK & 3,21 & UK & 2,90 & Italy & 1,55 \\
Japan & 1,03 & Japan & 0,18 & Greece & 1,09 \\
Germany & 0,41 & Euronext & $-0,28$ & Euronext & 0,58 \\
Euronext & $-0,86$ & Germany & $-0,60$ & Austria & 0,17 \\
Spain & $-0,94$ & Spain & $-0,94$ & Spain & 0,00 \\
Ireland & $-0,96$ & Italy & $-1,03$ & EMU & $-0,02$ \\
EMU & $-1,30$ & EMU & $-1,33$ & Finland & $-0,10$ \\
Finland & $-2,37$ & Greece & $-1,60$ & UK & $-0,32$ \\
Austria & $-2,44$ & Ireland & $-2,05$ & Japan & $-0,85$ \\
Italy & $-2,59$ & Austria & $-2,27$ & Germany & $-1,01$ \\
Greece & $-2,69$ & Finland & $-2,47$ & Ireland & $-1,08$ \\
& & & & & \\
\hline
\end{tabular}




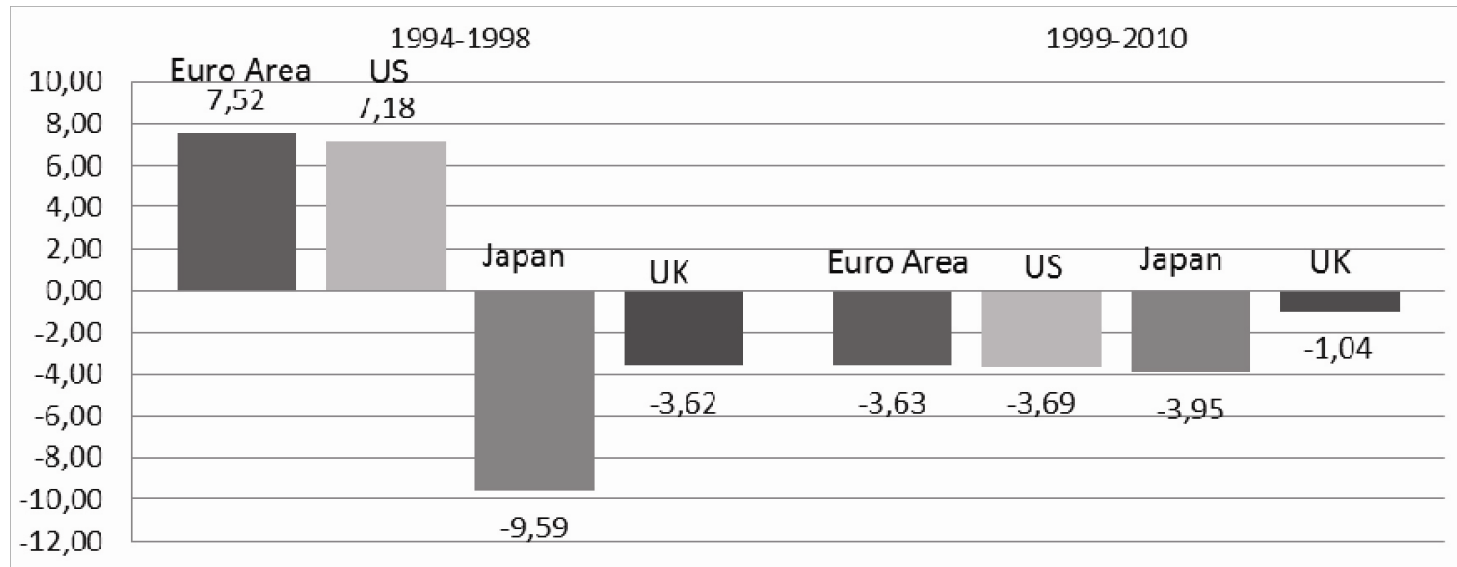

Figure 1. Average yearly changes of market capitalization ( $\%$ of world) in the Euro area, the United States, Japan, and UK

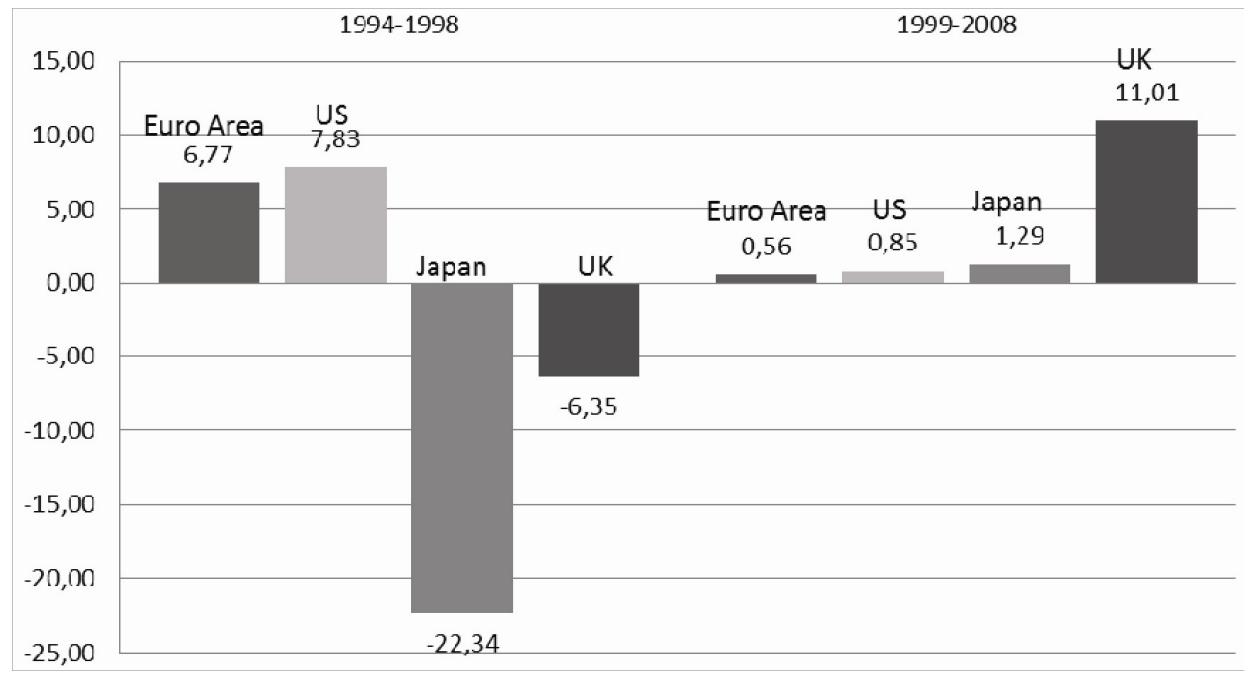

Figure 2. Average yearly changes of the value of share trading ( $\%$ of world) in the Euro area, the United States, Japan, and UK

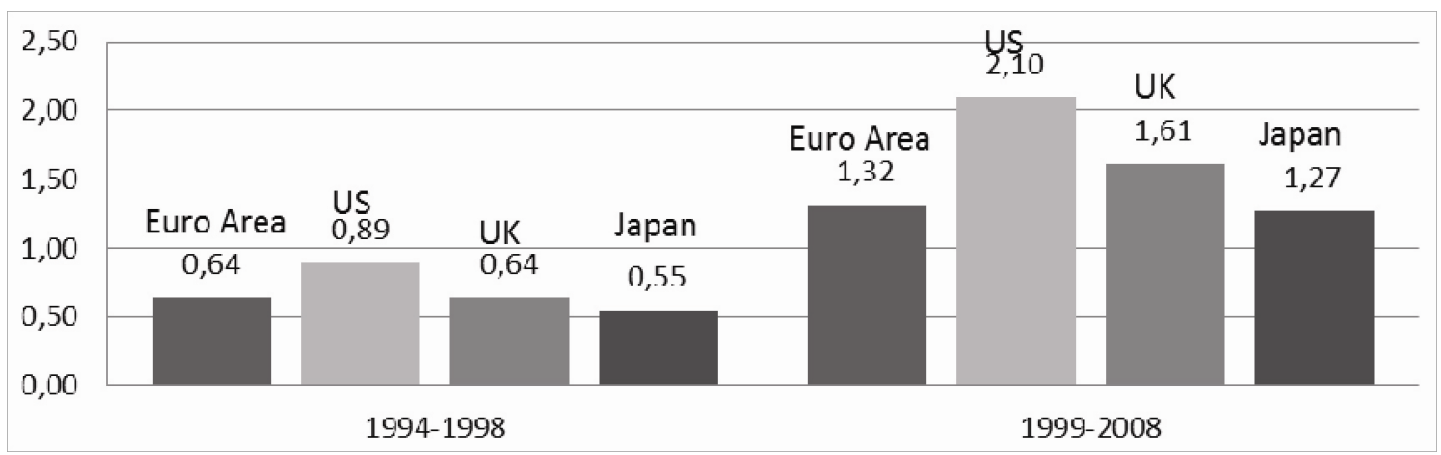

Figure 3. Turnover ratio in the Euro Area, the United States, the UK, and Japan (yearly average) 